\title{
Persepsi mahasiswi terhadap beauty vlogger dan dampaknya pada keputusan pembelian make-up
}

\author{
Maya Suryani $^{1}$, Fitria Rahmi², Nelia Afriyeni ${ }^{3}$ \\ ${ }^{1}$ Prodi Psikologi, Fakultas Kedokteran Universitas Andalas, email : mayasuryani27@gmail.com \\ ${ }^{2}$ Prodi Psikologi, Fakultas Kedokteran Universitas Andalas, email : fitriarahmi01@gmail.com \\ ${ }^{3}$ Prodi Psikologi, Fakultas Kedokteran Universitas Andalas, email : neliaafriyeni@yahoo.com
}

\section{ARTICLE INFO ABSTRACT}

Article history:

Received 29 September 2021

Received in revised 30 September 2021

Accepted 15 Oktober 2021

Available online 29 Oktober 2021
The study aims to see the effect of college student perception to beauty vlogger on the purchase decision of make-up products. The methods used in this research are quantitative methods, with incidental sampling forms and subjects for this research amounted to 201 college students in the city of Padang. These data are analyzed with simple regression analysis. The results showed that there was an effect of college student perceptions of beauty vlogger on purchasing decisions for make-up products $\mathrm{p}=0,000(\mathrm{p}<0.05)$, which was $22 \%$, meaning that the better the perception of beauty vlogger, the higher the purchasing decision and the remaining $78 \%$ is influenced by other variables not examined in this study.

Keywords: student, beauty vlogger, purchase decision

\begin{abstract}
Abstrak
Penelitian ini bertujuan untuk melihat pengaruh persepsi mahasiswi kepada beauty vlogger terhadap keputusan pembelian produk make-up. Metode yang digunakan dalam penelitian ini adalah metode kuantitatif, dengan bentuk sampling insidental dan jumlah subjek pada penelitian ini berjumlah 201 orang mahasiswi di kota Padang. Data yang didapat tersebut dianalisis menggunakan analisis regresi sederhana. Hasil penelitian menunjukkan bahwa terdapat pengaruh persepsi mahasiswi kepada beauty vlogger terhadap keputusan pembelian produk make-up $\mathrm{p}=0,000(\mathrm{p}<0.05)$ yaitu sebesar $22 \%$, artinya semakin baik persepsi terhadap beauty vlogger maka semakin tinggi pula keputusan pembelian, sedangkan sisanya $78 \%$ dipengaruhi oleh variabel lain yang tidak diteliti dalam penelitian ini.
\end{abstract}

Kata Kunci: mahasiswa, beauty vlogger, keputusan pembelian.

\section{PENDAHULUAN}

Perkembangan produk kosmetik saat ini sangatlah pesat, hampir bagi setiap wanita, kosmetik merupakan kebutuhan sehari-hari. Penampilan merupakan modal dan investasi yang sangat penting, karena pada dasarnya wanita ingin selalu tampil cantik dan menarik. Menurut Wilujeng dan Edwar (2014), kosmetik merupakan produk yang unik karena selain produk ini memiliki kemampuan untuk memenuhi kebutuhan mendasar wanita akan kecantikan sekaligus menjadi sarana bagi konsumen untuk memperjelas identitas dirinya secara sosial di matamasyarakat.

Pada penelitian ini, peneliti memfokuskan pada produk kosmetik riasan (make-up) yang digunakan untuk mempercantik penampilan. Salah satu strategi yang digunakan oleh produsen kosmetik riasan (make- 
up) dalam mempromosikan produknya adalah melalui internet. Berdasarkan riset Zap Beauty Index yang dilakukan pada bulan Mei-Juni 2018 didapatkan bahwa sebelum membeli produk kecantikan (kosmetik) secara online maupun offline, $73,2 \%$ wanita terlebih dulumencari review produk tersebutsecara online atau melalui internet.

Berdasarkan hasil surveylembaga pasar riset APJII (Asosiasi Penyelenggara Jasa Internet Indonesia, 2016) mahasiswa merupakan pengguna internet terbesar di Indonesia yakni sebesar 89,7\%. Kalangan mahasiswi merupakan salah satu kelompok sosial dalam masyarakat yang rentan terhadap pengaruh gaya hidup, trend, dan mode yang sedang berlaku.

Berdasarkan hasil riset Taylor Nelson Sofres menyatakan bahwamahasiswa memiliki peringkat yang paling tinggi dalam penggunaan YouTube dikarenakan mereka memiliki waktu luang yang banyak daripada yang sudah bekerja (dalam Mellyaningsih, 2016). Sebuah survei pada bulan Februari 2017, riset JakPat(sebuah aplikasi survei online) menemukan bahwa saluran tutorial adalah jenis saluran yang paling populer di antara pengguna YouTube di Indonesia. JakPat menemukan bahwa 54,0\% responden yang berlangganan YouTube berfokus padakonten tutorial (Chadha, 2017). Salahsatu konten tutorial yang ada di YouTube adalah konten tutorial tentang kecantikan yang dikenal dengan beauty vlog.

Beauty vlog yakni vlog yang berisikan tentang tutorial make up dan review produk kecantikan. Seseorang yang membuat konten beauty vlog dikenal sebagai beauty vlogger. Menurut Najihan (2017) beautyvlogger adalah seseorang yang membuat serta mengunggah video tentang kecantikan. Kecantikan di sinidiartikan sebagai apa yang digunakanberkaitan dengan skincare, makeup, atau alat kecantikan lainnya oleh beauty vlogger (Fischer, 2014).

Penggunaan media sosial sebagai cara bagi orang untuk mengekspresikan diri, termasuk beauty vlogger yang memposting hasil kreasi mereka di YouTube (Fischer, 2014). Beauty vlogger atau juga dikenal sebagai influencer kecantikan, mengunggah videomengenai ulasan makeup dan tutorialkecantikan di YouTube sehingga dapat mempengaruhi orang untukmemakai apa yang mereka gunakan (Faranisa \& Wandebori, 2016). Senada dengan yang disampaikanoleh Rahmawan (2017) bahwa vlogger dapat dilihat sebagai manifestasi konsep micro-celebrity serta online influencer atau selebritis online yang berpengaruh, terutama dikalangan anak muda. Sesuai dengan fenomena yang terjadi, maka banyak produk kosmetik yang secara tidaklangsung diperkenalkan oleh parabeauty vlogger.

Sebuah perusahaan platform pemasaran video yang Bernama Pixability bekerja sama dengan YouTube melakukan sebuah survei tentang vlogger yang kerap mengunggah panduan kecantikan ke YouTube. Survei tersebut menyatakanbahwa $61 \%$ wanita akan melihat video panduan kecantikan yang diunggah para vlogger di YouTube dan $38 \%$ wanita mengatakan akan membeli produk yang ditampilkan dalam video yang mereka lihat tersebut (dalam koran Sindo, 2016).

Sebelum memutuskan untuk melakukan pembelian, konsumen perlu mengetahui produk yang akan dibeli. Berbagai macam produk kosmetik make-up yang ada di pasaran, dan banyaknya kosmetik yang membahayakan membuat konsumen berhati-hati dalam memutuskan untuk membeli produk kosmetik. Menurut riset Zap Beauty Index, 2018 wanita Indonesia lebih mementingkan keamanan produk dan harga. Untuk menghindari kosmetik yang berbahaya tersebut, penting bagi konsumen untuk mencari informasimelalui video beauty vlogger mengenai produk kosmetik make-up sebelum melakukan keputusan pembelian.

Menurut Kotler dan Keller (2008) keputusan pembelian adalah tahap dalam proses pengambilan keputusan pembeli dimana konsumen benar-benar membeli. Ada beberapa faktor yang mempengaruhi keputusan pembelian seperti yang diungkapkan Kotler dan Keller (2008), salah satu diantaranya adalah faktor psikologis yakni persepsi. Menurut Schiffman dan Kanuk (2008) persepsi adalah proses yang dilakukan individu untukmemilih, mengatur dan menginterpretasikan stimuli untukmenciptakan gambaran keseluruhanyang berarti.

Persepsi dipengaruhi oleh objek yang dipersepsi itu sendiri, kecenderungan syaraf dan otak, dan pengalaman pribadi individu serta faktor-faktor lainnya dalammenginterpretasikan stimulus tersebut (Kotler \& Amstrong, 2008). Pada penelitian ini objek yang dipersepsikan adalah beauty vlogger. Menurut Forbes (2016) terdapat lima karakteristik beauty social influencer (beauty vlogger), yaitu relatability, knowledge, helpfulness, confidenece, articulation. Persepsi terhadap beauty vlogger pada penelitian ini dilihat melalui aspek persepsi menurut Schiffman (dalam Sukmana, 2003) yaitu kognisi dan afeksi digabungkan dengan karakteristik yang melekat pada beauty vlogger, yang secara tidak langsung akan membentuk persepsi konsumen terhadap beautyvlogger dan kemudian konsumen akan tertarik membeli produk hanya dengan melihat sebuah review yang diciptakan oleh beauty vlogger sehingga akhirnya memutuskan untukmembeli produk tersebut.

JURNAL ILMIAH MANAJEMEN DAN KEWIRAUSAHAAN Vol.1, No.2, Oktober 2021, pp. 167-172 


\section{TINJAUAN PUSTAKA}

\subsection{Keputusan Pembelian}

Pengertian keputusan pembelian, menurut Kotler dan Keller (2008) adalah tahap dalam proses pengambilan keputusan pembeli di mana konsumen benar-benar membeli. Menurut Kotler dan Keller (2008) salah satu proses keputusan membeli. Dalam melaksanakan pembelian,konsumen dapat membuat empat subkeputusan, yaitu:

1. Pilihan Produk

Perusahaan harus memusatkan perhatiannya kepada konsumen yang berminatmembeli sebuah produk atau jasaserta alternatif yang mereka pertimbangkan berdasarkandesign dan inovasi produk.

2. Pilihan Merek

Setiap merek memiliki perbedaan-perbedaan tersendiri, sehingga konsumen harus memutuskan merek mana yang akan dibeli. Pilihan merek merupakan alasan yang dipertimbangkan konsumendalam memilih merek. Hal ini meliputi kepercayaan, popularitas merek dan citraperusahaan produk tersebut.

3. Pilihan Penyalur

Setiap konsumen berbeda- beda dalam hal menentukan penyalur, dikarenakan faktor kemudahan mendapatkan barang, lokasi yang dekat, dan harga yang ditawarkan outlet atau toko.

4. Waktu Pembelian

Keputusan pembelian konsumen bisa dilakukan dalam pemilihan waktu yang berbedabeda, sesuai dengan kapan produk tersebut dibutuhkan.

\subsection{Persepsi Mahasiswi kepada BeautyVlogger}

Menurut Schiffman dan Kanuk (2008) persepsi adalah proses yang dilakukan individu untuk memilih, mengatur dan menginterpretasikan stimuli untuk menciptakan gambaran keseluruhan yang berarti. Menurut Schiffman (dalam Sukmana, 2003),persepsi memiliki beberapa aspek, yaitu:

1. Aspek kognisi

Aspek kognisi meliputi pandangan, penafsiran, dan penilaian individu terhadap objek yang dipersepsi. Hal ini berhubungan dengan pengertian, pengetahuan, dan pengenalan terhadap stimulus tertentu.

2. Aspek afeksi

Aspek afeksi meliputi perasaan individu dalam menghadapi objek persepsi.Penilaian individu terhadap suatuobjek didasarkan pada keadaanemosional.

Menurut Forbes (2016), beautyvlogger merupakan influencer yangmuncul di media sosial dan memiliki keterampilan dalam bidang make-up. Menurut Forbes (2016) terdapat limakarakteristik beauty social influencer(beauty vlogger), diantaranya sebagaiberikut:

1. Relatability

Influencer mampu membuat koneksi dengan audiens(penontonnya), mereka berbagi cerita dan pengalaman pribadi mengenai suatu produk yang menimbulkan hubungan simpatikdengan penonton.

2. Knowledge

Influencer memiliki wawasan atau pengetahuan mengenaibidang yang mereka tampilkan dan mampu menawarkan fakta- fakta yang jelas dan pasti tentang produk kepada penonton. Influencer memiliki pemahaman tentang bagaimana cara menggunakan produk dan kegunaan produk tersebut.

3. Helpfulness

Influencer membantu penonton dalam memahami kegunaan produk dan cara pengaplikasian yang tepat dalammenggunakan produk tersebut. Influencer memberikan saran dan pendapat yang digunakan dalam mempengaruhi keputusan konsumen terhadap suatu produk.

4. Confidence

Influencer percaya terhadap pernyataannya, keyakinan dankemampuannya. 
5. Articulation

Influencer secara jelas mengkomunikasikan danmenyajikan informasi dengan lancar untuk membantu penontondalam memahami produk, baiksecara verbal maupun visual.

\section{METODOLOGI PENELITIAN}

Metode penelitian yang digunakan pada penelitian ini adalah metode penelitian kuantitatif. Penelitian kuantitatif menghasilkan data penelitian berupa angka-angka dan analisis menggunakan metode statistik (Azwar, 2011). Pada penelitian ini sampel yang digunakan berjumlah 201 orang. Teknik pengambilan sampel menggunakan nonprobability sampling denganbentuk accidental sampling.

Metode pengumpulan data pada penelitian ini berupa skala psikologi. Skala pengukuran yang digunakan adalah skala persepsi mahasiswi kepada beauty vlogger yang dibuat sendiri oleh peneliti, disusun berdasarkan aspek persepsi dari Schiffman (dalam Sukmana, 2003) digabungkan dengan karakteristik beauty vlogger yang dikembangkan dari oleh Forbes (2016). Selanjutnya keputusan pembelian diukur dengan modifikasi dari skala yang dibuat oleh Amelia (2016). Skala ini dibuat dari teori yang disampaikan oleh Kotler dan Keller (2008). Uji reliabilitas pada skala persepsi terhadap beauty vlogger didapatkan sebesar 0,961 dan reliabilitas keputusan pembelian sebesar 0,921.

\section{HASIL DAN PEMBAHASAN}

Penelitian ini menggunakananalisis uji regresi linear sederhana. Hasil penelitian menunjukkan bahwa terdapat pengaruh persepsi mahasiswikepada beauty vlogger terhadap keputusan pembelian produk makeup. Persepsi mahasiswi kepada beauty vlogger memberikan pengaruh sebesar $22 \%$ terhadap keputusan pembelian produk make-up dan sisanya $78 \%$ adalah pengaruh lainnya ditentukan oleh variabel lain yang tidak diteliti dalam penelitian ini.

Hasil ini juga menunjukkan bahwa pengaruh persepsi mahasiswi kepada beauty vlogger terhadap keputusan pembelian produk make-upmemiliki arah yang positif. Artinya semakin baik persepsi mahasiswi kepada beauty vlogger maka semakin tinggi pula keputusan pembelian. Begitu pula sebaliknya, yaitu ketika persepsi mahasiswi kepada beauty vlogger buruk maka akan semakin rendah keputusan pembelian. Hal ini didukung oleh Rahmi (2018) yang menyatakan bahwa semakin baik persepsi terhadap beauty vlogger,maka tinggi pula konsumen mengarahkannya pada pengambilankeputusan.

Sesuai dengan Rahmi (2018) yang menyatakan terdapat hubungan antara persepsi terhadap beauty vlogger pada pengambilan keputusan konsumen untuk pembelian sebuah produk. Menurut Kotler dan Keller (2008) persepsi merupakan salah satu faktor psikologis yang mempengaruhi keputusan pembelian. Hasil ini juga didukung oleh penelitian sebelumnyayang menunjukkan bahwa faktor persepsi konsumen mempunyai pengaruh terhadap keputusan pembelian pada produk shampoSunsilk dan Clear, pembelian Hunian Green Product, serta pembelian polis asuransi pada nasabah Prudential di Kota Samarinda (Awaliyah, 2010; Wardhani, Sumarwan, \&Yuliati, 2015; Silva, 2017).

Lebih lanjut, hasil penelitian terhadap kedua variabel yaitu persepsi terhadap beauty vlogger dan keputusan pembelian dianalisis secara deskriptif. Berdasarkan hasil analisis deskriptif didapatkan bahwa persepsi terhadap beauty vlogger berada pada kategori baik dengan jumlah responden 199 orang dan 2 orang mahasiswi yang berada pada kategoriburuk. Berdasarkan hasil menunjukkan bahwa sebagian besar mahasiswi memiliki persepsi yang baik terhadap beauty vlogger. Secara umum hal ini berarti mahasiswi memiliki penilaian atau interpretasi yang baik dalam memandang beauty vlogger ketika memberikan review, sehingga dapat mempertimbangkan rekomendasi dan review produk yang diberikan oleh beauty vlogger.

Persepsi kepada beauty vlogger dapat dilihat berdasarkan aspek-aspek persepsi dan karakterisitik beautyvlogger. Karakteristik yang memiliki nilai mean tertinggi adalah relatability, hal ini menunjukkan bahwa mahasiswi merasa beauty vlogger mampu membangun hubungan dengan penontonnya. Hal ini terlihat dari hasil skala psikologi pada mahasiswi dimana beauty vlogger dinilai memiliki cara menarik dalam memberikan review produk, terbuka menceritakan masalah pada wajahnya dan mengungkapkan kesukaannya terhadap sebuah produk.

Analisis deskriptif juga dilakukan terhadap variabel keputusan pembelian, didapatkan hasil bahwa keputusan pembelian produk make-up pada kategori tinggi dengan jumlah responden 186 orang dan 15 mahasiswi berada pada kategorisasi rendah. Hal ini berartisebagian besar mahasiswi berada pada tahap dalam proses pengambilankeputusan untuk membeli produkmake-up.

JURNAL ILMIAH MANAJEMEN DAN KEWIRAUSAHAAN Vol.1, No.2, Oktober 2021, pp. 167-172 
Pada gambaran keputusan pembelian produk make-up menunjukkan bahwa mahasiswi mengambil keputusan dalam membeli pada beberapa dimensi. Dimensi yang memiliki nilai mean tertinggi yaitu dimensi waktu pembelian, ini memperlihatkan bahwa mahasiswi memutuskan membeli produk meke-up dalam waktu yang berbeda-beda sesuai dengan kapan produk tersebutdibutuhkan. Menurut Kotler dan Armstrong (2008) keputusan pembelian adalah konsumen yang telah menetapkan pilihannya terutama berdasarkan kebutuhan yangsesungguhnya. Sesuai dengan hasil skala psikologi peneliti kepada mahasiswi, bahwa mahasiswi melakukan keputusan pembelian produk make-up karenamenggunakan produk make-up dalamkeseharian untuk menunjang penampilannya atau ketika akan menggunakannya dalam waktu dekat, sehingga dapat memenuhikebutuhannya pada saat itu.

\section{KESIMPULAN DAN SARAN}

\section{Kesimpulan}

1. Terdapat pengaruh positif dan siginifikan antara persepsi mahasiswi kepada beauty vlogger terhadap keputusan pembelian

produk make-up. Hal ini berarti semakin baik persepsi mahasiswi kepada beauty vlogger maka akan semakin tinggi pula keputusan pembelian produk make-up. Begitu juga sebaliknya semakin buruk persepsi mahasiswi kepada beauty vlogger maka akan semakinrendah pula keputusan pembelian produk make-up.

2. Berdasarkan kategorisasi tampak bahwa sebagian besar mahasiswi memiliki persepsi yang baik terhadap beauty vlogger.

3. Berdasarkan kategorisasi tampakbahwa sebagian besar mahasiswi memiliki keputusan pembelianyang tinggi terhadap produk make-up.

\section{Saran}

Saran Metodologis

Peneliti selanjutnya dapat menggunakan variable lain atau menambahkan faktor lain yang mempengaruhi keputusan pembelian seperti faktor sosial atau faktor psikologis lainnya sepertipengetahuan dan kepercayaan. Selain itu, untuk kedepannya agar lebih memperhatikan penggabungan skala persepsi kepada beauty vlogger.

\section{Saran Praktis}

1. Bagi pihak konsumen, mahasiswi diharapkan mampu membuat perhitungan dan analisa sebelum memutuskan untuk membeli produk dan menjadikan beautyvlogger yang memiliki reputasi yang baik sebagai salah satu sumber informasi dalam pencarianproduk make-up.

2. Bagi pihak terkait (produsen dan marketing), hasil penelitian ini dapat menjadi informasi baru bagi produsen dan marketing bahwa beauty vlogger dapat menjadi

\section{DAFTAR PUSTAKA}

Amelia, Yance. 2016. Hubungan antara word of mouth communication dengan keputusan pembalian smartphone Asus pada mahasiswa Universitas Andalas. Skripsi. Psikologi. Fakultas Kedokteran. Universitas Andalas.

APJJI. 2016. Hasil Survei Internet APJII 2016. https://apjii.or.id/survei2016 (13 Agustus 2017).

Awaliyah, Ratih Fadlilah. 2010. Analisis pengaruh persepsi konsumen dan bonus dalam kemasan terhadap keputusan pembelian. Skripsi. ManajemenPemasaran. Fakultas Ekonomidan Bisnis. Universitas Islam Negeri Syarif Hidayatullah Jakarta.

Azwar, S. (2011). Dasar-dasar psikometri. Yogyakarta: Pustaka Belajar.

BPOM. 2011. Peraturan KepalaBadan Pengawas Obat dan Makanan Republik Indonesia Tentang Metode AnalisisKosmetika. Jakarta: Sekretariat Negara.

Chadha, Rahul ; YouTube Users in Indonesia Drawn to Education OverEntertainment. https://www.emarketer.com. Diakses pada tanggal 17 Oktober2017, pukul 19.01 WIB. 
Faranisa, A. A., \& Wandebori, H. (2016). The impact of drugstore makeup product reviews by beauty vlogger on youtube towards purchase intention by undergraduate students inIndonesia. International Conference on Ethics of Business, Economics, and SocialScience. 264-273.

Fischer, T. (2014). Makeup, YouTube, and amateur media in the Twenty-First Century. University of Calgary: Undergraduate Film Journal, 2014(13), 1-8.

Kotler, P \& Armstrong, G. (2008). Prinsip-prinsip Pemasaran Edisi 12 Jilid 1. Alih Bahasa : Sihombing, D. Jakarta: Erlangga2008

Kotler, P., \& Keller, K. L. (2008). Manajemen Pemasaran Edisi 12Jilid1. AlihBahasa : Molan, B. Jakarta: PT. Indeks.

Mellyaningsih, Adinda. (2016). Motif subscriber menonton channel youtube Raditya Dika. Jurnal EKomunikasi, 4 (1), 1-12.

Najihan, Nur Rafika Tien. (2017). Efektivitas beauty vlogger dalam meningkatkan minat beli produk kecantikan. Ilmu Sosial dan Humaniora, 4 (1), 1-14.

Rahmi, Andella. 2013. Hubungan persepsi terhadap beauty vlogger dengan pengambilan keputusan konsumen untuk pembelian produk maybelline. Skripsi. Psikologi. Fakultas Ilmu Pendidikan. Universitas Negeri Padang.

Schiffman, L. G., \& Kanuk, L. L.(2008). Perilaku konsumen. Edisi 7. Diterjemahkan oleh: Z. Kasip.Jakarta: INDEKS Kelompok Gramedia,

Silva, P. M. (2017). Pengaruh persepsi konsumen dan motivasi konsumen terhadap keputusan pembelian polis asuransi.PSIKOBORNEO, 5(3), 427-440.

Sukmana. (2003). Dasar-dasar psikologi lingkungan. Malang:UMM Press.

Wardhani, W., Sumarwan, U., \& Yuliati, L. N. (2015). Pengaruh persepsi dan preferensi konsumen terhadap keputusan pembelian hunian green product. Jurnal Manajemen dan Organisasi, VI(1), 4563.

Wilujeng, S. R., \& M., Edwar. (2014). Pengaruh brand awareness dan brand trust terhadap keputusan pembelian produk oriflame.Jurnal Penelitian FakultasEkonomi, 2(1), 1-15. 